\title{
ASSESSMENT OF HIGH SALINITY WASTEWATER TREATMENT WITH DEWATERED ALUM SLUDGE-AEROBIC MEMBRANE REACTOR
}

\begin{abstract}
The discharge of wastewater containing both high salinity and high organic content without prior treatment is detrimental to aquatic life and water hygiene. In order to integrate the advantages of membrane treatment and biological treatment, and exert the phosphorus removal efficiency of dewatered alum sludge, in this study, an aerobic membrane reactor based on dehydrated alum sludge was used to treat mustard tuber wastewater with salinity of 6.8-7.3\% under the conditions of $30{ }^{\circ} \mathrm{C}, 20 \mathrm{kPa}$ trans-membrane pressure (TMP) and chemical oxygen demand (COD) of $3300-3900 \mathrm{mg} / \mathrm{L}$. Three replicate reactors were applied to assess the operational performance under different organic loading rate (OLR). The results showed that all reactors were effective in removing COD, ammonia nitrogen $\left(\mathrm{NH}_{4}{ }^{+}-\mathrm{N}\right)$ and soluble phosphate (SP) under the conditions of $30{ }^{\circ} \mathrm{C}$ and $20 \mathrm{kPa}$ of TMP. Meanwhile, the effluent concentration of $\mathrm{COD}, \mathrm{NH}_{4}{ }^{+}-\mathrm{N}$ and $\mathrm{SP}$ all increased while OLR was changed from 1.0 to $3.0 \mathrm{~kg} \mathrm{COD} / \mathrm{m}^{3} /$ day, and the effluent COD and $\mathrm{NH}_{4}{ }^{+}-\mathrm{N}$ concentration except for SP could reach the B-level of Chinese "Wastewater quality standards for discharge to municipal sewers" when OLR was less than $3.0 \mathrm{~kg} \mathrm{COD} / \mathrm{m}^{3} /$ day. This indicates that dewatered alum sludge-based aerobic membrane reactor is a promising bio-measure for treating high salinity wastewater.
\end{abstract}

Keywords: organic loading rate, biological treatment, membrane treatment, high salinity wastewater, trans-membrane pressure

\section{Introduction}

Fuling District, Chongqing is famous for its mustard tuber production market. During the manufacturing process, large amount of wastewater containing $0.3-20 \mathrm{~g} / \mathrm{L}$ organic compounds and 0.5-7 g/L suspended solid are produced. Meanwhile, the wastewater is also detected with high salinity of 2-15\%, which will inevitably inhibit the biological treatment efficiency, considering the following aspects: (1) high salinity inhibits the activity of many enzymes in cell, and ultimately lead to plasmolysis [1,2]; (2) high salt in wastewater affects anaerobic ammonium oxidation, nitrification and denitrification [3-5]; (3) high salinity reduces dissolved organic carbon (DOC), soluble phosphate and biochemical oxygen demandremoval rate [6-8].

In order to solve the above problems, a lot of researches on biological treatment technology have been carried out in recent years. Gaoet al. [9] adopted a system combining an anaerobic fluidised bed (AFB) with microbial fuel cell (MFC) to treat high salinity

\footnotetext{
${ }^{1}$ Key Laboratory of Yellow River and Huai River Water Environmental and Pollution Control, Ministry of Education, Henan Normal University, 453007, China, phone +86-18323216594, ORCID: WK 0000-0003-1750-6799, XC 0000-0001-9437-1360, YC 0000-0002-2331-8527, LB 0000-0002-5730-8909, KM 0000-0003-4858-6429

*Corresponding author: loulantingxue@126.com
} 
wastewater, and the anode attained good removal efficiency of $98.6 \%$ for chemical oxygen demand (COD) and $52.1 \%$ for ammonia nitrogen $\left(\mathrm{NH}_{4}{ }^{+}-\mathrm{N}\right)$ when the $\mathrm{Cl}^{-}$concentration was $<6500 \mathrm{mg} / \mathrm{L}$. A cyclic activated sludge system (a new technology of sequencing batch reactor (SBR) process evolution) was used to treat mixed mustard wastewater and urban sewage, and all indicators were stable to meet urban sewage treatment plant pollutant discharge standards when mixing ratio was less than $30 \pm 1 \%$ [10]. Considering the simple structure and low operation cost, SBR was used to treat high salinity wastewater by Tatoulis et al. [11] and Deorsola et al. [12], and removal rate of dissolved COD reached $96.5 \%$ when initial COD concentration and operating mode of trickling filter were $7500 \mathrm{mg} / \mathrm{L}$ and SBR with recirculation, respectively. Considering upflow anaerobic sludge blanket (UASB) process has various advantages such as high efficiency and withstanding organic shock loading, a laboratory scale UASB reactor was adopted to treat synthetic wastewater at a hydraulic retention time (HRT) of $24 \mathrm{~h}$, finally achieving a $88 \%$ total organic carbon (TOC) removal efficiency under $2 \%$ salinity and $1 \mathrm{~g} / \mathrm{L} \mathrm{NH}_{4}{ }^{+} \mathrm{N}[13,14]$.

For better treating high salinity wastewater, membrane technology is also introduced and integrated into biological treatment. Lu et al. [15] adopted sequencing batch biofilm reactor to treat synthetic wastewater containing $14 \mathrm{~g} / \mathrm{L}$ salinity, and the removal efficiency of COD reached $88.0 \%$ at an OLR of $0.96 \mathrm{~kg} \mathrm{COD} / \mathrm{m}^{3} /$ day. As membrane bioreactor (MBR) has greater biomass retention time and less sludge production than conventional aerobic reactor, Yang et al. [16] and Dan et al. [17] used different MBRs to treat high salinity wastewater, and the maximum COD removal rate of yeast membrane bioreactor reached $0.93 \mathrm{~g} \mathrm{COD} / \mathrm{g} \mathrm{MLSS} /$ day at $\mathrm{F} / \mathrm{M}$ of $1.5 \mathrm{~g} \mathrm{COD} / \mathrm{g} \mathrm{MLSS} /$ day. Considering membrane fouling problems, many hybrid MBRs have been developed to eliminate this drawback [18]. A forward osmosis membrane bioreactor with thin film composite membrane and seeded with flocculated sludge or aerobic granules was used to treat synthetic wastewater with $1 \mathrm{M} \mathrm{NaCl}$ draw solution. The result showed the removal efficiencies of TOC, $\mathrm{NH}_{4}{ }^{+}-\mathrm{N}$ and phosphate were 100, 43.0 and $96.0 \%$, respectively [19]. Patsios et al. [20] used a moving bed biofilm reactor-membrane bioreactor (MBBR-MBR) to treat real high-strength, saline wastewater from a table olive processing plant under three different HRTs of 88, 96 and $104 \mathrm{~h}$, and the removal efficiencies of TOC and total polyphenols (TPh) were 85.6 and $89.1 \%$, respectively.

For a long time, the exploration of low-cost adsorbent and its application in wastewater treatment have been the focus of attention among by-products or wastes in various industries. Waterworks sludge is a by-product of coagulation, flocculation and other water treatment processes in drinking water treatment plants, which composition is complex, and the waterworks sludge is rich in aluminium, iron, calcium and other elements. To a certain extent, it is a waste of resources to bury it or throw it into the sea. Alum sludge has strong predictive adsorption capacity for phosphorus and is higher than most other typical low-cost adsorbents [21, 22]. Zhao et al. [23] and Yang et al. [24] integrated the alum sludge into a constructed wetland system for P-rich wastewater treatment. The results demonstrated that alum sludge can increase the phosphorus removal efficiency, and active bacteria attached growth on the alum sludge can effectively remove organic matter and $\mathrm{NH}_{4}{ }^{+}$-N. In addition, there are studies to indicate that P-adsorption capacity would be reduced with the increase of alum sludge particle sizes, and $\mathrm{P}$ recovery after the alum sludge reuse is feasible from a technical point of view [25].

Many studies have shown that the membrane fouling in anaerobic membrane bioreactor was more intense than aerobic membrane bioreactor, and alum sludge can 
increase the phosphorus removal efficiency [26, 27]. Membrane fouling is an unavoidable phenomenon that affects membrane performance during membrane separation operation, which refers to the adsorption and accumulation of pollutants on the membrane surface or in membrane pores, and the concentration polarization caused by it. The appearance of membrane fouling not only reduces the membrane flux, but also changes the membrane's ability to intercept and separate solutes [28, 29]. The dewatered alum sludge-based aerobic membrane reactor was designed for mustard tuber wastewater treatment in this study. By studying the influence of organic loading rate (OLR) on COD, $\mathrm{NH}_{4}{ }^{+}-\mathrm{N}$ and soluble phosphate (SP), the treatment efficiency of this novel reactor for high salinity wastewater was evaluated.

\section{Materials and methods}

\section{Experiment setting}

The schematic of aerobic membrane reactor based on dehydrated alum sludge is shown in Figure 1. The effective volume of this reactor was $405 \mathrm{~L}$, with size of $L \times B \times H=1.08 \times 0.75 \times 0.50 \mathrm{~m}$. This reactor was made of Polyvinyl chlorideboard, which includes aerobic zone and membrane zone, and the length ratio of each zone was 7:2. Aerobic zone included porous aeration head and semi-soft biofilm-packing with $30 \%$ biofilm density. Membrane zone included 2-3 $\mathrm{mm}$ aperture aeration pipe and polyvinylidene fluoride hollow fiber membrane. The membrane area of this hollow fiber membrane was $1 \mathrm{~m}^{2}$.

High-efficiency halotolerant bacteria in this aerobic membrane reactor based on dehydrated alum sludge were selected from the wastewater produced in the processing of pickling mustard tuber. Such bacteria would be inoculated into the aerobic zone of this aerobic membrane reactor.

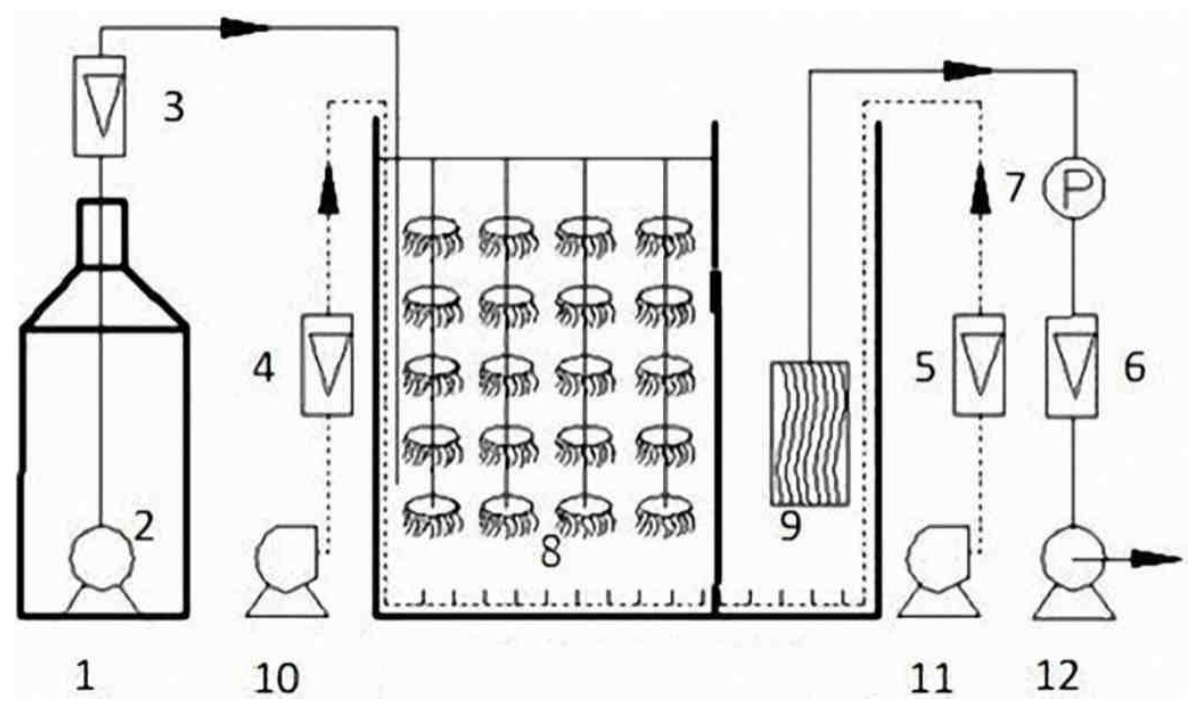

Fig. 1. Schematic of aerobic membrane reactor based on dehydrated alum sludge: 1 - bucket, 2 - submersible pump, 3-6 - flowmeter, 7 - vacuum meter, 8 - biofilm-packing, 9 - fiber membrane, 10-11 - aeration pump, 12 - dump pump 


\section{Dewatered alum sludge and wastewater}

The experimental dewatered alum sludge was collected from the industrial filter press of the sludge dewatering unit of a local water treatment plant in Chongqing, China, where aluminium sulphate was used as coagulant. Thereafter, the dewatered alum sludge was air-dried at room temperature for 10 days. The air-dried dewatered alum sludge was then ground and sieved to prepare the sludge for batch P-adsorption test, and the percentage of dewatered alum sludge added to biological sludge was 2-5\%. The main physicochemical properties of dewatered alum sludge were shown in Table 1. During the experimental process, the influent salinity mass fraction was controlled to be 4.0, 4.5, 5.0, 5.5, 6.0, 6.5 and $7.0 \%$, respectively. The acclimatization process under a specific salinity mass fraction was considered to be finished if the COD removal rate could reach $80.0 \%$ stably. Then, the influent salinity mass fraction would be raised to the next level until it reached $7.0 \%$.

Table 1

Main physicochemical properties of dewatered alum sludge

\begin{tabular}{|c|c|c|c|c|c|c|c|}
\hline Index & $\begin{array}{c}\text { Total } \\
\text { phosphorus } \\
(\mathbf{T P})\end{array}$ & $\begin{array}{c}\text { Active } \\
\text { aluminum } \\
\left(\mathbf{A l}_{\mathbf{~} \mathbf{x}}\right)\end{array}$ & $\begin{array}{c}\text { Active } \\
\text { iron } \\
\left(\mathbf{F e}_{\text {ox }}\right)\end{array}$ & $\mathbf{A l}$ & $\mathbf{F e}$ & $\mathbf{C a}$ & $\mathbf{M g}$ \\
\hline Concentration $[\mathrm{g} / \mathrm{kg}]$ & 0.48 & 56.65 & 8.56 & 58.70 & 9.25 & 5.36 & 5.45 \\
\hline
\end{tabular}

The experimental wastewater was taken from the second pickle liquid of Fuling Mustard Tuber Group by Share Ltd, China; detailed composition was listed in Table 2. During the manufacture process of mustard tuber, the first pickle liquid contained more impurity, which could accelerate membrane fouling of experimental equipment. At the same time, the third pickle liquid possessed a relatively higher salinity, which could be reused in the production of mustard tuber sauce.

Table 2

The quality of experimental wastewater

\begin{tabular}{|c|c|}
\hline Parameter & Concentration \\
\hline COD [mg/L] & $3300-3900$ \\
\hline Total nitrogen (TN) [mg/L] & $320-380$ \\
\hline $\mathrm{NH}_{4}^{+}-\mathrm{N}[\mathrm{mg} / \mathrm{L}]$ & $140-210$ \\
\hline $\mathrm{SP}[\mathrm{mg} / \mathrm{L}]$ & $50-62$ \\
\hline Salinity [\%] & $6.8-7.3$ \\
\hline Suspended solids $(\mathrm{SS})[\mathrm{mg} / \mathrm{L}]$ & $340-420$ \\
\hline
\end{tabular}

\section{Experimental procedure}

Parallel tests were carried out using three groups of reactors. All reactors in this experiment were operated in intermittent mode. The influent was transported into the reactor through submersible pump, and floating ball was used to control liquid level. The effluent of this reactor was transported through self-priming pump, and the working state of this pump was running for $8 \mathrm{~min}$ and stopping for $1 \mathrm{~min}$. The effect of different trans-membrane pressure (TMP) on membrane fouling rate was studied in previous experiments, and the optimal TMP was selected in this experiment. Therefore, TMP in this experiment is a fixed value. The dissolved oxygen concentration of aerobic zone, aeration intensity (ratio of air to water) of membrane zone, TMP of fiber membrane and temperature were $4.0-5.0 \mathrm{mg} / \mathrm{L}, 12 \mathrm{~m}^{3} / \mathrm{m}^{2} / \mathrm{h}, 20 \mathrm{kPa}$ and $30{ }^{\circ} \mathrm{C}$, respectively. As tank volume and 
influent concentration remained unchanged, the OLR depended on influent flow rate. According to preliminary test results and water quantity, the OLRs of this experiment were determined as 1.0, 2.0 and $3.0 \mathrm{~kg} \mathrm{COD} / \mathrm{m}^{3} /$ day, and the influence of different OLR on the removal of $\mathrm{COD}, \mathrm{NH}_{4}{ }^{+}-\mathrm{N}$ and $\mathrm{SP}$ was studied in this study.

\section{Analyses}

Detection parameters during the experiment consisted of the following items: COD, $\mathrm{NH}_{4}{ }^{+}-\mathrm{N}$ and SP. These parameters were analysed on the basis of standard methods for the Examination of Water and Wastewater which was released by American Public Health Association [30]. Samples were analysed with the standardised photometric cuvette tests from Hach-Lange for COD. For SP determination, sample pretreatment including filtration through $0.45 \mathrm{~mm}$ Millipore filters was necessary due to the large quantities of solids were present. Removal efficiencies were obtained by calculating the percentages of corresponding pollutant removal from the influent concentrations. In this study, the effluent concentration needs to meet Chinese "Wastewater quality standards for discharge to municipal sewers", and the different level of Chinese "Wastewater quality standards for discharge to municipal sewers" is presented in Table 3.

Table 3

Quality of Chinese wastewater quality standards for discharge to municipal sewers

\begin{tabular}{|c|c|c|c|}
\hline \multirow{2}{*}{ Parameter } & \multicolumn{3}{|c|}{ Concentration } \\
\cline { 2 - 4 } & A-level & B-level & C-level \\
\hline $\mathrm{COD}[\mathrm{mg} / \mathrm{L}]$ & 500 & 500 & 300 \\
\hline $\mathrm{NH}_{4}{ }^{+}-\mathrm{N}[\mathrm{mg} / \mathrm{L}]$ & 45 & 45 & 25 \\
\hline Total phosphorus (TP) $[\mathrm{mg} / \mathrm{L}]$ & 8 & 8 & 5 \\
\hline
\end{tabular}

\section{Results and discussion}

\section{COD removal under different OLRs}

The influent and effluent COD concentrations of dewatered alum sludge-based aerobic membrane reactor under different OLRs were shown in Figure 2.

It can be seen that when the influent COD concentration is $3480 \mathrm{mg} / \mathrm{L}$, the COD removal efficiency shows a gradual decreasing trend with the gradual increase of OLR. The maximum removal efficiency was $96.6 \%$ when the OLR was $1.0 \mathrm{~kg} \mathrm{COD} / \mathrm{m}^{3} / \mathrm{day}$, and the minimum removal efficiency was $72.1 \%$ when the OLR was $3.0 \mathrm{~kg} \mathrm{COD} / \mathrm{m}^{3} / \mathrm{day}$. At the same time, when the OLR was more than $2.0 \mathrm{~kg} \mathrm{COD} / \mathrm{m}^{3} /$ day, the COD concentration of effluent cannot meet the B-grade standard of Chinese "Wastewater quality standards for discharge to municipal sewers". Considering all factors, the OLR of $2.0 \mathrm{~kg} \mathrm{COD} / \mathrm{m}^{3} /$ day is the best.

With the increase of OLR, the number of microorganism increased, which lead to the increase of biofilm thickness. Meanwhile, this lead to anaerobic decomposition of biofilm's interior, which accelerated biofilm abscission [31]. At the same time, high OLR would result in uncompleted degradation due to poor biodegradability level [32]. Aloui et al. [33] adopted an activated sludge unit to treat an industrial wastewater containing 1-6\% salt, and investigated the influence of OLR on COD removal rate after 18 days of treatment in continuous mode. The COD removal rate decreased with the increase of OLR, and a total detoxification of the saline wastewater was achieved with salt concentrations below 
$2 \%$ and OLR under $855 \mathrm{mg} / \mathrm{L} /$ day. Furthermore, the increase of OLR might also cause a partial disintegration of granules, thus resulting in the increase in effluent COD concentration [34-36].

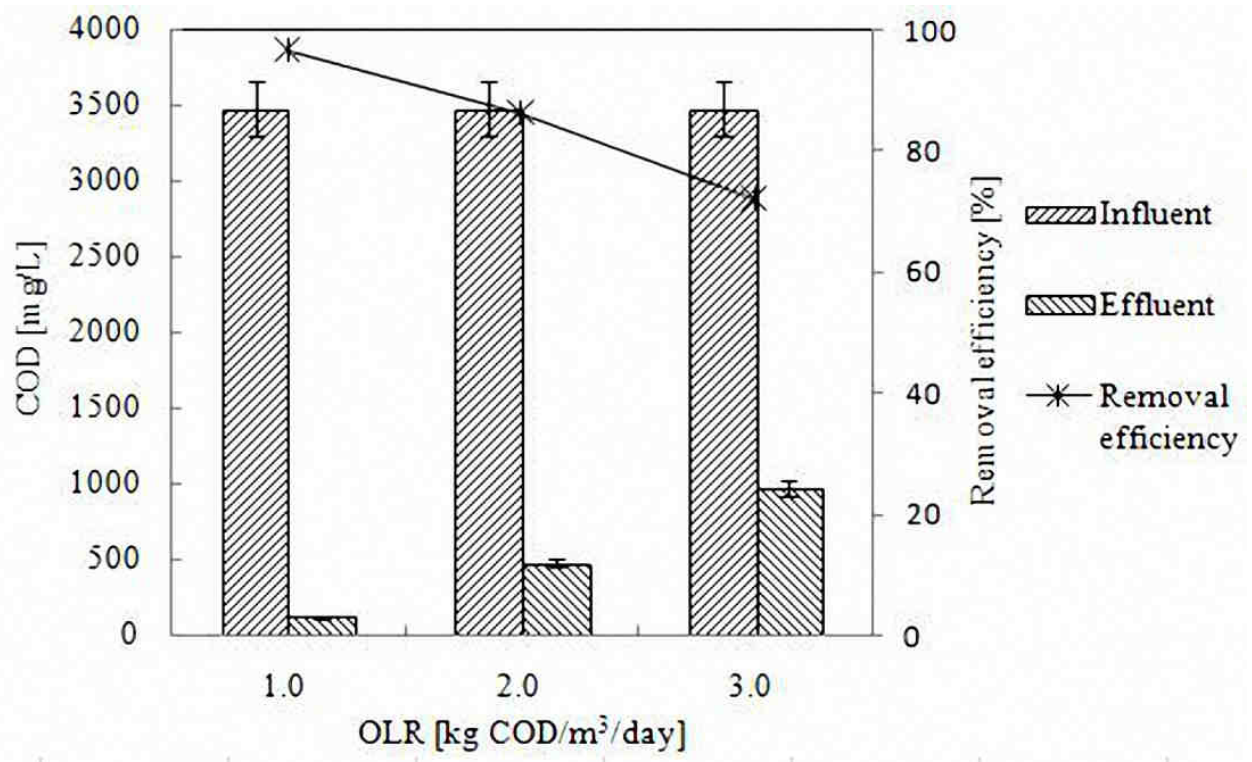

Fig. 2. COD removal under different organic loading rate

\section{$\mathrm{NH}_{4}{ }^{+}-\mathrm{N}$ removal under different OLRs}

The influent and effluent $\mathrm{NH}_{4}{ }^{+}-\mathrm{N}$ concentrations of dewatered alum sludge-based aerobic membrane reactor under different OLRs were shown in Figure 3.

As can be seen from Figure 3, when the influent $\mathrm{NH}_{4}{ }^{+}-\mathrm{N}$ concentration was $169 \mathrm{mg} / \mathrm{L}$, the $\mathrm{NH}_{4}{ }^{+}-\mathrm{N}$ removal efficiency showed a gradual decreasing trend with the gradual increase of OLR. The maximum removal efficiency was $94.1 \%$ when the OLR was $1.0 \mathrm{~kg} \mathrm{COD} / \mathrm{m}^{3} /$ day, and the minimum removal efficiency was $74.0 \%$ when the OLR was $3.0 \mathrm{~kg} \mathrm{COD} / \mathrm{m}^{3} / \mathrm{day}$. At the same time, even if the OLR was more than $2.0 \mathrm{~kg} \mathrm{COD} / \mathrm{m}^{3} / \mathrm{day}$, the $\mathrm{NH}_{4}{ }^{+} \mathrm{N}$ concentration of effluent can still meet the B-grade standard of Chinese "Wastewater quality standards for discharge to municipal sewers". Considering all the above factors, we believe that the OLR value of $3.0 \mathrm{~kg} \mathrm{COD} / \mathrm{m}^{3} /$ day is relatively reasonable.

The analysis showed that, the higher OLR caused the more labile organic compounds content, which lead to the competition of heterotrophic bacteria and autotrophic bacteria, eventually caused the decrease of nitrification ability and the enhancement of denitrification ability [37]. Meanwhile, due to the dependence of nitrification on the supply of oxygen, the nitrification process of organic compounds would be inhibited when the OLR exceeded oxygen transfer rate [38, 39]. Jiang et al. [40] used food waste to study the influence of $\mathrm{pH}$, temperature, and OLR on $\mathrm{NH}_{4}{ }^{+}-\mathrm{N}$, and found that the concentration of $\mathrm{NH}_{4}{ }^{+}-\mathrm{N}$ was lower due to a lower OLR and death of some fermentative microorganisms. 


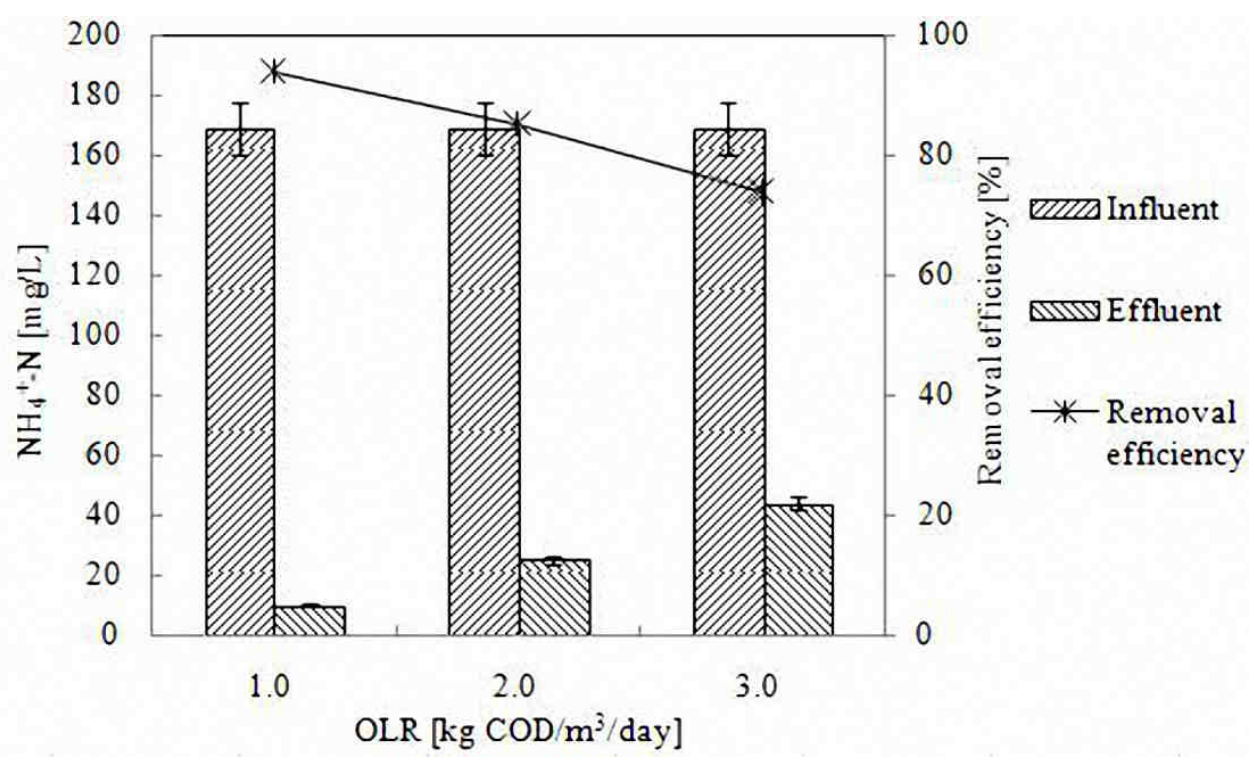

Fig. 3. $\mathrm{NH}_{4}{ }^{+}-\mathrm{N}$ removal under different organic loading rate

\section{SP removal under different OLRs}

The influent and effluent SP concentrations of dewatered alum sludge-based aerobic membrane reactor under different OLRs were shown in Figure 4.

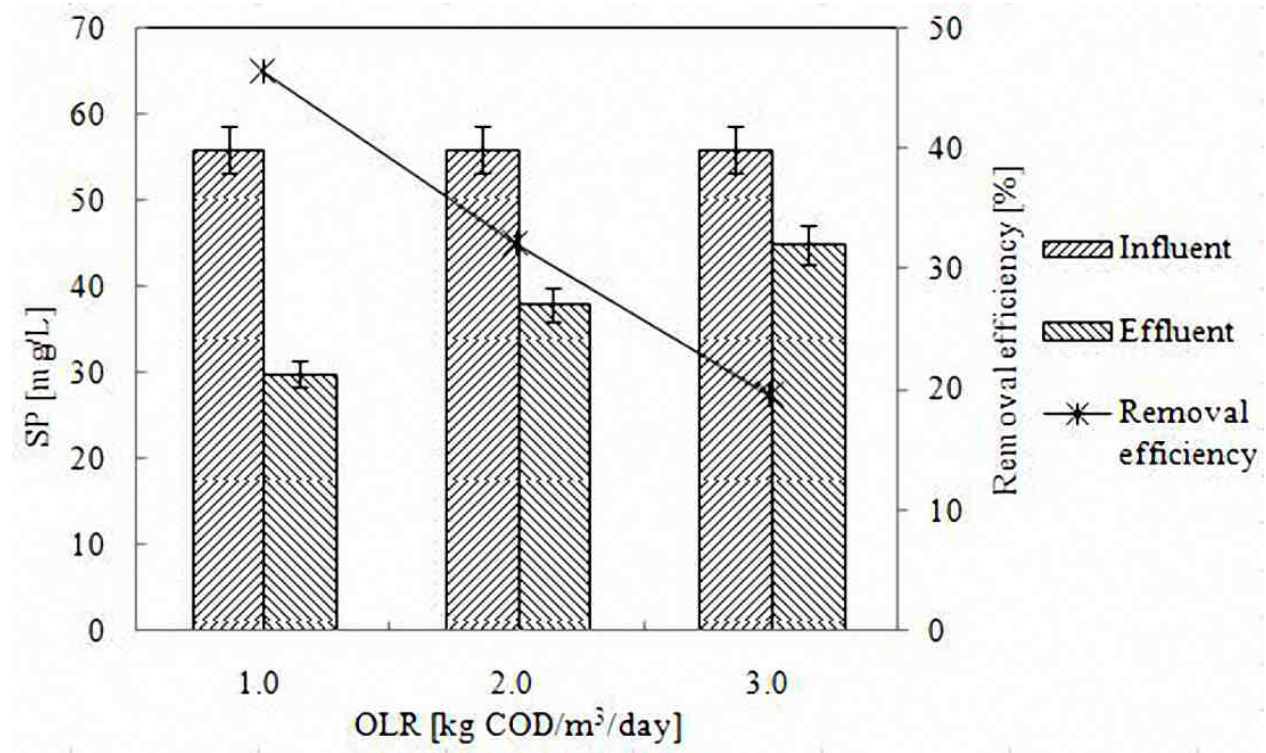

Fig. 4. SP removal under different organic loading rate 
Figure 4 was a description of the decrease of SP under different organic loading rate. It can be seen that when the influent SP concentration was $56 \mathrm{mg} / \mathrm{L}$, the removal efficiency of SP showed a gradual decrease trend with the gradual increase of OLR, and the maximum removal efficiency was $46.4 \%$ when the OLR was $1.0 \mathrm{~kg} \mathrm{COD} / \mathrm{m}^{3} /$ day. Even so, the SP concentration in wastewater cannot meet any level of Chinese "Wastewater quality standards for discharge to municipal sewers".

In this experiment, no excessive sludge was discharged during the operation period, and the demand for phosphate of microorganism was small. Therefore, the removal of SP was dependent on phosphate reduction system rather than phosphate accumulating organisms [41]. At the same time, when OLR changed from 1.0 to $3.0 \mathrm{~kg} \mathrm{COD} / \mathrm{m}^{3} / \mathrm{day}$, the effluent $\mathrm{pH}$ increased from 8.0 to 8.9 , which would inhibit the activities of phosphate reduction bacteria [42]. However, the decreasing tendency of TP concentration in this experiment was not obvious. This may suggest that phosphate ions replaced - $\mathrm{OH}$ on the surface of dewatered alum sludge, which deduced that ligand exchange was the dominating pathway for phosphate removal $[43,44]$.

\section{Conclusion}

The dewatered alum sludge-based aerobic membrane reactor operating at $30{ }^{\circ} \mathrm{C}$ and $20 \mathrm{kPa}$ of TMP was used to treat mustard tuber wastewater with salinity of $6.8-7.3 \%$. The effluent concentration of $\mathrm{COD}, \mathrm{NH}_{4}{ }^{+}-\mathrm{N}$ and SP all increased while OLR was changed from 1.0 to $3.0 \mathrm{~kg} \mathrm{COD} / \mathrm{m}^{3} /$ day, and the effluent $\mathrm{COD}$ and $\mathrm{NH}_{4}{ }^{+}-\mathrm{N}$ concentration except for SP could reach the B-level of Chinese "Wastewater quality standards for discharge to municipal sewers" when OLR was less than $3.0 \mathrm{~kg} \mathrm{COD} / \mathrm{m}^{3} /$ day. At the same time, the change of temperature and $\mathrm{pH}$ in this experiment was very small, which has little effect on the removal of these experimental parameters. These data can effectively show that the aerobic membrane reactor based on dehydration alum sludge is a promising biological measure for treating high salinity wastewater.

\section{Acknowledgements}

The work reported here was financially supported by China National Science Foundation Program (Grant No.51908199), China Postdoctoral Science Foundation (Grant No.2019M652547), Scientific Research Starting Foundation of Henan Normal University (Grant No.qd18019).

\section{References}

[1] Pendashteh AR, Fakhru'l-Razi A, Madaeni SS, Abdullah LC, Abidin ZZ, Biak DRA. Membrane foulants characterization in a membrane bioreactor (MBR) treating hypersaline oily wastewater. Chem Eng J. 2011;168:140-50. DOI: 10.1016/j.cej.2010.12.053.

[2] Zhang XH, Gao J, Zhao FB, Zhao YY, Li ZS. Characterization of a salt-tolerant bacterium Bacillus sp from a membrane bioreactor for saline wastewater treatment. J Environ Sci. 2014;26:1369-74. DOI: 10.1016/S1001-0742(13)60613-0.

[3] Osaka T, Shirotani K, Yoshie S, Tsuneda S. Effects of carbon source on denitrification efficiency and microbial community structure in a saline wastewater treatment process. Water Res. 2008;42:3709-18. DOI: 10.1016/j.watres.2008.06.007.

[4] Aslan S, Simsek E. Influence of salinity on partial nitrification in a submerged biofilter. Bioresour Technol. 2012;118:24-9. DOI: 10.1016/j.biortech.2012.05.057. 
[5] Chen YP, Ma TF, Hu X, Fang F, Shen Y, Yang JX, et al. Start-up of a combined anaerobic/partial nitritation/anammox process for high-salt mustard wastewater treatment. Appl Biochem Biotechnol. 2015;175:119-34. DOI: 10.1007/s12010-014-1247-X.

[6] Song XY, McDonald J, Price WE, Khan SJ, Hai FI, Ngo HH, et al. Effects of salinity build-up on the performance of an anaerobic membrane bioreactor regarding basic water quality parameters and removal of trace organic contaminants. Bioresour Technol. 2016;216:399-405. DOI: 10.1016/j.biortech.2016.05.075.

[7] Qu WD, Li JY, Han GX, Wu HT, Song WM, Zhang XS. Effect of salinity on the decomposition of soil organic carbon in a tidal wetland. J Soil Sediment. 2019;19:609-17. DOI: 10.1007/s11368-018-2096-y.

[8] Rovirosa N, Sanchez E, Cruz M, Veiga MC, Borja R. Coliform concentration reduction and related performance evaluation of a down-flow anaerobic fixed bed reactor treating low-strength saline wastewater. Bioresour Technol. 2004;94:119-27. DOI: 10.1016/j.biortech.2003.12.010.

[9] Gao YX, Liu SX, Cai Q, Li HD, Yang P. Effects of chloride ion on performance and microbial community in an anaerobic fluidized bed microbial fuel cell. Environ Eng Sci. 2019;36:1214-23. DOI: 10.1089/ees.2019.0102.

[10] Chai HX, Wei ZW, Kang W, Wei YH, Du J, Zhou J, et al. Biological treatment of mustard tuber wastewater and urban sewage by cyclic activated sludge system. Asian J Chem. 2014;26:3261-4. DOI: 10.14233/ajchem.2014.17505.

[11] Tatoulis TI, Zapantiotis S, Frontistis Z, Akratos CS, Tekerlekopoulou AG, Pavlou S, et al. A hybrid system comprising an aerobic biological process and electrochemical oxidation for the treatment of black table olive processing wastewaters. Int Biodeterioration Biodegr. 2016;109:104-12. DOI: 10.1016/j.ibiod.2016.01.013.

[12] Deorsola AB, Camarinha GC, Carvalho DD, Sant'Anna GL. Biological treatment of saline wastewaters in an aerobic sequencing batch reactor. Environ Prog Sustain. 2013;32:198-205. DOI: 10.1002/ep.10634.

[13] Gomec CY, Gonuldinc S, Eldem N, Ozturk I. Behavior of an up-flow anaerobic sludge bed (UASB) reactor at extreme salinity. Water Sci Technol. 2005;51:115-20. DOI: 10.2166/wst.2005.0397.

[14] Aslan S, Sekerdag N. Salt inhibition on anaerobic treatment of high salinity wastewater by upflow anaerobic sludge blanket (UASB) reactor. Desalin Water Treat. 2016;57:12998-3004. DOI: 10.1080/19443994.2015.1059369.

[15] Lu J, Yan X, Ma YF, Tian CX, Ding JC. Impact of salinity on treatment of saline wastewater by sequencing batch biofilm reactor process. J Cent South Univ. 2014;21:1989-94. DOI: 10.1007/s11771-014-2147-5.

[16] Yang JX, Spanjers H, Jeison D, Van Lier JB. Impact of $\mathrm{Na}^{+}$on biological wastewater treatment and the potential of anaerobic membrane bioreactors: A review. Crit Rev Environ Sci Technol. 2013;43(24):2722-46. DOI: 10.1080/10643389.2012.694335.

[17] Dan NP, Visvanathan C, Polprasert C, Ben Aim R. High salinity wastewater treatment using yeast and bacterial membrane bioreactors. Water Sci Technol. 2002;46:201-9. DOI: 10.2166/wst.2002.0239.

[18] Li J, Yu DS, Wang D. Experimental test for high saline wastewater treatment in a submerged membrane bioreactor. Desalin Water Treat. 2011;36:171-7. DOI: 10.5004/dwt.2011.2253.

[19] Huang LY, Lee DJ, Lai JY. Forward osmosis membrane bioreactor for wastewater treatment with phosphorus recovery. Bioresour Technol. 2015;198:418-23. DOI: 10.1016/j.biortech.2015.09.045.

[20] Patsios SI, Kontogiannopoulos KN, Pouliou N, Karabelas AJ. Performance of a membrane bioreactor and a moving bed biofilm reactor-membrane bioreactor treating table olive processing wastewater: a comparative study. J Chem Technol Biotechnol. 2021;96(4):1030-9. DOI: 10.1002/jctb.6614.

[21] Wang LM, Wang X, Yang F, Kong M, Peng FQ, Chao JY, et al. Nitrogen removal performance and ammonia- and nitrite-oxidizing bacterial community analysis of a novel industrial waste-based biofilter. Chem Eng J. 2016;299:156-66. DOI: 10.1016/j.cej.2016.04.082.

[22] Liu RB, Mao Y, Shen C, Zhao YQ. Can biofilm affect alum sludge adsorption: An engineering scope in a novel biofilm reactor for wastewater treatment. Chem Eng J. 2017;328:683-90. DOI: 10.1016/j.cej.2017.07.081.

[23] Zhao YQ, Babatunde AO, Zhao XH, Li WC. Development of alum sludge-based constructed wetland: An innovative and cost effective system for wastewater treatment. J Environ Sci Health A. 2009;44(8):827-32. DOI: 10.1080/10934520902928685.

[24] Yang Y, Zhao YQ, Wang SP, Guo XC, Ren YX, Wang L, et al. A promising approach of reject water treatment using a tidal flow constructed wetland system employing alum sludge as main substrate. Water Sci Technol. 2011;63(10):2367-73. DOI: 10.2166/wst.2011.575.

[25] Zhao XH, Zhao YQ, Wang WK, Yang YZ, Babatunde A, Hu YS, et al. Key issues to consider when using alum sludge as substrate in constructed wetland. Water Sci Technol. 2015;71(12):1775-82. DOI: 10.2166/wst.2015.138.

[26] Lin HJ, Peng W, Zhang MJ, Chen JR, Hong HC, Zhang Y. A review on anaerobic membrane bioreactors: Applications, membrane fouling and future perspectives. Desalination. 2013;314:169-88. DOI: 10.1016/j.desal.2013.01.019. 
[27] Skouteris G, Hermosilla D, Lopez P, Negro C, Blanco A. Anaerobic membrane bioreactors for wastewater treatment: A review. Chem Eng J. 2012;198:138-48. DOI: 10.1016/j.cej.2012.05.070.

[28] Liu JW, Kang XY, Luan XR, Gao LT, Tian HY, Liu XL. Performance and membrane fouling behaviors analysis with SVR-LibSVM model in a submerged anaerobic membrane bioreactor treating low-strength domestic sewage. Environ Technol Innov. 2020;19:100844. DOI: 10.1016/j.eti.2020.100844.

[29] Wang HQ, Zhang HN, Zhang KF, Qian YX, Yuan X, Ji BX, et al. Membrane fouling mitigation in different biofilm membrane bioreactors with pre-anoxic tanks for treating mariculture wastewater. Sci Total Environ. 2020;724:138311. DOI: 10.1016/j.scitotenv.2020.138311.

[30] APHA. Standard Methods for Water and Wastewater Examination, 22nd ed. Washington. Amer Public Health Assn, 2012. ISBN: 9780875530130.

[31] Val del Rio A, Figueroa M, Mosquera-Corral A, Campos JL, Mendez R. Stability of aerobic granular biomass treating the effluent from a seafood industry. Int J Environ Res. 2013;7:265-76. DOI: 10.1016/j.envsoft.2012.08.007.

[32] Corsino SF, Capodici M, Morici C, Torregrossa M, Viviani G. Simultaneous nitritation-denitritation for the treatment of high-strength nitrogen in hypersaline wastewater by aerobic granular sludge. Water Res. 2016;88:329-36. DOI: 10.1016/j.watres.2015.10.041.

[33] Aloui F, Khoufi S, Loukil S, Sayadi S. Performances of an activated sludge process for the treatment of fish processing saline wastewater. Desalination. 2009;246:389-96. DOI: 10.1016/j.desal.2008.03.062.

[34] Di Bella G, Torregrossa M. Simultaneous nitrogen and organic carbon removal in aerobic granular sludge reactors operated with high dissolved oxygen concentration. Bioresour Technol. 2013;142:706-13. DOI: 10.1016/j.biortech.2013.05.060.

[35] Chai HX, Li L, Wei YH, Zhou J, Kang W, Shao ZY, et al. Optimization of membrane fouling process for mustard tuber wastewater treatment in an anoxic-oxic biofilm-membrane bioreactor. Environ Eng Res. 2016;21:196-202. DOI: 10.4491/eer.2015.093.

[36] Jorfi S, Ghafari S, Ramavandi B, Soltani RDC, Ahmadi M. Biodegradation of high saline petrochemical wastewater by novel isolated halotolerant bacterial strains using integrated powder activated carbon/activated sludge bioreactor. Environ Prog Sustain. 2019;38:13088. DOI: 10.1002/ep.13088.

[37] Oyanedel V, Campos JL, Garrido JM, Lazarova V, Mendez R. Development of a membrane-assisted hybrid bioreactor for ammonia and COD removal in wastewaters. J Chem Technol Biotechnol. 2005;80:206-15. DOI: $10.1002 /$ jetb.1180.

[38] Ramos AF, Gómez MA, Hontoria E, González-López J. Biological nitrogen and phenol removal from saline industrial wastewater by submerged fixed-film reactor. J Hazard Mater. 2007;142:175-83. DOI: 10.1016/j.jhazmat.2006.08.079.

[39] Saikaly P, Ayoub GM. Ammonia nitrogen removal in step-feed rotating biological contactors. Water Air Soil Pollut. 2003;150:177-91. DOI: 10.1023/A:1026164530805.

[40] Jiang JG, Zhang YJ, Li KM, Wang Q, Gong CX, Li ML. Volatile fatty acids production from food waste: Effects of $\mathrm{pH}$, temperature, and organic loading rate. Bioresour Technol. 2013;143:525-30. DOI: 10.1016/j.biortech.2013.06.025.

[41] Devai I, Felfoldy L, Wittner I, Plosz S. Detection of phosphine: New aspects of the phosphorus cycle in the hydrosphere. Nature. 1988;333:343-5. DOI: 10.1038/333343a0.

[42] Kang W, Chai HX, Yang SW, Du GJ, Zhou J, He Q. Influence of organic loading rate on integrated bioreactor treating hypersaline mustard wastewater. Biotechnol Appl Biochem. 2016;63:590-4. DOI: 10.1002/bab.1396.

[43] Huang SH, Chiswell B. Phosphate removal from wastewater using spent alum sludge. Water Sci Technol. 2000;42(3-4):295-300. DOI: 10.2166/wst.2000.0394.

[44] Yang Y, Zhao YQ, Babatunde AQ, Wang L, Ren YX, Han Y. Characteristics and mechanisms of phosphate adsorption on dewatered alum sludge. Sep Purif Technol. 2006;51(2):193-200. DOI: 10.1016/j.seppur.2006.01.013. 